\title{
In Vitro Assessment Of The Antiplasmodial Activity Of Three Plants Extracts Used In Local Traditional Medicine In Saloum (Senegal)
}

\author{
Ousmane Niass \\ Serigne Omar Sarr
}

Laboratoire de Chimie Analytique et Bromatologie, Faculté de Médecine et Pharmacie Université Cheikh Anta DIOP de Dakar, Dakar-Fann Sénégal

\section{Baba Dieye}

Laboratoire de Parasitologie et Mycologie, Université Cheikh Anta Diop, Dakar, Sénégal

Amadou Diop

Yerim Mbagnick Diop

Laboratoire de Chimie Analytique et Bromatologie,

Faculté de Médecine et Pharmacie Université Cheikh Anta DIOP de Dakar, Dakar-Fann Sénégal

doi: 10.19044/esj.2016.v12n12p157 URL:http://dx.doi.org/10.19044/esj.2016.v12n12p157

\begin{abstract}
Against the scourge of malaria in Africa and the development of chemo-resistance, discovering new natural cures is a major concern for many researchers. As a consequence, the present study was carried out in order, first, to identify the phytochemical compounds, and second, to assess the antiplasmodial activity, of three medicinal plants extracts, selected from an ethno-botany survey conducted in Senegal. The parts of the plants used were Strychnos spinosa (Strychnaceae) leaves and stems, Combretum glutinosum (Combretaceae) barks, and the whole aerial part of Pennisetum polystachion (Poaceae). Among these plants, the hydromethanolic extracts of Strychnos spinosa stems showed the most important activity against Plasmodium falciparum strains, with a $\mathrm{IC}_{50}$ of $15 \mu \mathrm{g} / \mathrm{ml}$, followed by the leaves chlorophormic extracts and the ethyl acetate extracts of Pennisetum polystachion, with respective $\mathrm{IC}_{50}$ of $20 \mu \mathrm{g} / \mathrm{ml}$ and $21 \mu \mathrm{g} / \mathrm{ml}$. Combretum glutinosum extracts showed the least important activity, in all tests.
\end{abstract}

Keywords: Plasmodium, activity, extracts, medicinal plants. 


\section{Introduction}

Malaria remains the most important parasitic disease in the world, and is caused by protozoa of which the most dreadful species is Plasmodium falciparum. The development and spreading of plasmodial strains, resistant to anti-malaria drugs available today, are a threat to public health, hence the necessity to try to find new anti-malaria drugs. Prior works carried out on traditional medicinal plants allowed the discovery of efficient anti-malaria molecules such as quinine and artemisinin. Several African traditional plants were also tested and used in the prevention and treatment of malaria, including mango leaves (Madu, 2007), Picralimanitida various organs (Erharuyi \& al, 2014), Caricapapaya, Azadirachtaindica, Icacinasenegalensis leaves (Sarret \& al, 2011). Some studies have indicated that lemon grass was successfully used to treat drugs resistant malarial fever and typhoid (Akininyi, 2006). This encourages exploring plants for the discovery of new natural anti-malarial drugs (Schwikkard, 2002).

In such a context, an ethno-botany survey with traditional healers in Senegal allowed selecting three medicinal plants, of which, Strychnos spinosa (Strychnaceae), Combretum glutinosum (Combretaceae) and Pennisetum polystachion (Poaceae). These plants are used against malaria (Strychnos spinosa) but also against some bacterial infections (Combretum glutinosum and Pennisetum polystachion).

The objective of the present study is to identify, first, the phytochemical compounds and, second, to evaluate in vitro the antiplasmodial activity of these plants used in traditional medicine in Senegal.

\section{Materials and Methodology \\ Plant material}

The plant material is composed of Strychnos spinosa leaves and stems, Combretum glutinosum barks, and all the aerial part of Pennisetum polystachion.

\section{Blood samples preparation}

The blood used was taken from subjects suffering from simple $P$. falciparum malaria confirmed by thick drop and thin smear. Once in the laboratory, the blood was transferred in a $15 \mathrm{ml}$ tube, then a thin smear was done to assess the parasite load, and the tube is centrifuged at 2000 revolutions/mn for ten minutes, so as to separate the plasma and the blood corpuscles. Two other centrifugations, in the presence of non-supplemented RPMI, was carried out to rid the latter of any immunity components. 


\section{Parasites culture}

The cleaned samples are put in a culture medium, if the parasite load were contained between the interval of 0.4 - 1\%. If the parasite load were higher than 1\%, it is adjusted with $\mathrm{O}^{+}$blood; if by contrast it is lower than $0.4 \%$, blood will not be used in this study.

For culture purpose, the hematocrit were adjusted at $2 \%$ with complete RPMI; and with a multi-ducts pipette, $180 \mu \mathrm{l}$ of parasitized blood was distributed in the plates filled, beforehand, with $20 \mu$ l of plants extracts at different levels of concentrations. The culture medium thus prepared was blended, placed in a tightly closed container, exposed to a gaseous atmosphere $\left(1 \% \mathrm{O}_{2}, 5 \% \mathrm{CO}_{2}\right.$, and $\left.94 \% \mathrm{~N}_{2}\right)$, then incubated at $37^{\mathrm{O}} \mathrm{C}$ for 48 hours. After a while, a thin smear was done to check parasites growth (reinvasion) and the absence of contamination.

\section{Plant material preparation}

Fresh parts of plants were collected and after botanic identification, these various parts were dried in the shade at room temperature $\left(25^{\circ} \mathrm{C}\right)$, at Cheikh Anta Diop University of Dakar, Laboratory of Analytical Chemistry and Bromatology, and then reduced to fine powder with a grinder.

\section{Extraction}

A mass of $20 \mathrm{~g}$ of powder was macerated in $200 \mathrm{ml}$ of a mixture of methanol/water in a 50/50 (v/v) proportion, for 24 hours. That mixture of solvent and plant powder was filtered through filter-paper and then concentrated with a rotating evaporator. The concentrated extract was dried in an incubator between 37 and $45^{\circ} \mathrm{C}$.

$30 \mathrm{~g}$ of powder from the various plants parts was macerated in $300 \mathrm{ml}$ of solvents (methanol, chloroform, diethyl ether, ethyl acetate). The mixtures was filtered through filter-paper and then concentrated with a rotating evaporator.

For Strychnos, $100 \mathrm{~g}$ of plant power were put in $500 \mathrm{ml}$ of water at $90^{\circ} \mathrm{C}$ (Atsushi and al, 2004); after cooling an equal volume of methanol was added.

\section{Determination of the phytochemical compounds}

The phytochemical compounds was determined according to the methodology described by Trease and Evans (1997), with methanol/water based extracts (50/50; v/v). 


\section{Preparing extracts solutions}

With $1 \mathrm{mg} / \mathrm{ml}$ of base concentration prepared as follows: $10 \mathrm{mg}$ of extracts was dissolved in $1 \mathrm{ml}$ of DMSO, and then completed with RPMI at $10 \mathrm{ml}$, before being submitted to Ultrasone for $15 \mathrm{mn}$.

It was from that base solution that the following concentrations were prepared, that is to say: $6 \mu \mathrm{g} / \mathrm{ml}, 12.5 \mu \mathrm{g} / \mathrm{ml}, 25 \mu \mathrm{g} / \mathrm{ml}, 50 \mu \mathrm{g} / \mathrm{ml}$. To comply with the plasmodium cells culture conditions, supplemented RPMI was used to compose these concentrations. The total DMSO percentage is lower than $0.1 \%$, for all tests.

\section{In vitro testing of antiplasmodial activity}

The antiplasmodial activity was tested on parasites according to the DAPI ex vivo dosage methodology (Ndiaye and al, 2010). Briefly, $180 \mu$ of supplemented RPMI containing parasitized red blood in $2 \%$ of hematocrit were distributed in plates of 96 holes preloaded with $20 \mu$ l of solutions diluted in series of plants extracts. Extract concentrations vary from 6-50 $\mu \mathrm{g} / \mathrm{ml}$. Besides, in each plate, there are 6-8 negative control holes, with the culture medium alone.

Parasites were cultured for $48-72$ hours at $37^{\circ} \mathrm{C}$ in standard air conditions $\left(1 \% \mathrm{O}_{2}, 5 \% \mathrm{CO}_{2}, 94 \% \mathrm{~N}_{2}\right)$, before adding the solution of 4', 6diamidino-2-phenilyndol (DAPI) (Banieki and al, 2007; Ndiaye and al, 2010).

Data were collected by measuring the fluorescence relative units (RFU), using a Fluoroskan plate reader (Thermo Scientific; ex 358 nm, em $461 \mathrm{~nm})$.

\section{Data statistical analysis}

The dynamic variation of the DAPI trial ex vivo was assessed by calculating the signal-to-noise ratio (SNR) and the Z' factor of each test. The SNR was measured by dividing the fluorescence signal (RFU) from holes without extract, by the maximum fluorescence signal of holes with extracts.

Statistical analysis was carried out with GraphPadPrism software programme (v5.0d, San Diego, CA), which allowed calculating some $\mathrm{IC}_{50}$ values, according to a non linear regression model.

\section{Results}

Table I below represents the throughput in mass percentage, of extractions carried out with various solvents. 
Table I: Extractions throughput in mass percentage

\begin{tabular}{cccccc}
\hline \multicolumn{7}{c}{ Extractions throughput in \% } \\
\hline $\begin{array}{c}\text { Extraction } \\
\text { solvents }\end{array}$ & Methanol/Water & $\begin{array}{c}\text { Ethyl } \\
\text { acetate }\end{array}$ & Chloroform & $\begin{array}{c}\text { Diethyl } \\
\text { ether }\end{array}$ & methanol \\
\hline C. glutinosum & 8.0 & 1.2 & 0.8 & 1.0 & 6.2 \\
P. polystachion & 9.6 & 2.4 & 1.8 & 1.7 & 6.5 \\
S. spinosa (leaves) & 11.6 & 3.8 & 2.0 & 3.2 & 10.9 \\
S. spinosa (stems) & 8.2 & 2.8 & 3.1 & 1.7 & 8.1 \\
\hline
\end{tabular}

The figures represent the throughputs values

Table II below shows the phytochemical compounds of selected plants hydromethanolic extracts.

Table II: Phytochemical compounds of hydromethanolic extracts.

\begin{tabular}{|c|c|c|c|c|c|c|}
\hline Plants & flavonoids & Tannins & $\begin{array}{l}\text { Anthracene } \\
\text { heterosides }\end{array}$ & $\begin{array}{l}\text { Cardiotonic } \\
\text { heterosides }\end{array}$ & Saponosides & Alcaloids \\
\hline P. & + & + & - & + & - & - \\
\hline polystachion & + & + & - & + & - & - \\
\hline $\begin{array}{l}\text { S. spinosa } \\
\text { C. } \\
\text { glutinosum }\end{array}$ & + & + & - & + & - & - \\
\hline
\end{tabular}

Figures 1-5 below represent the in vitro tests results of the antiplasmodial activity of the various plants used.

Figure 1: Antiplasmodial activity of Combretum glutinosum extracts

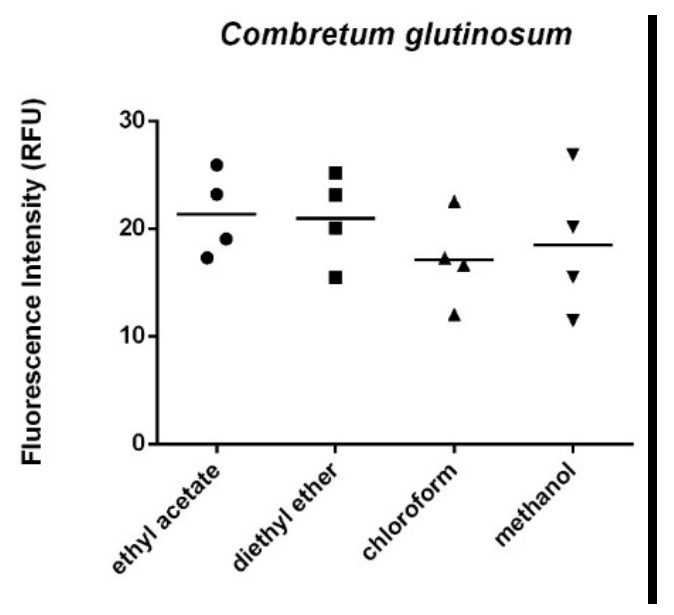

Figure 2: Antiplasmodial activity of Hydromethanolic extracts

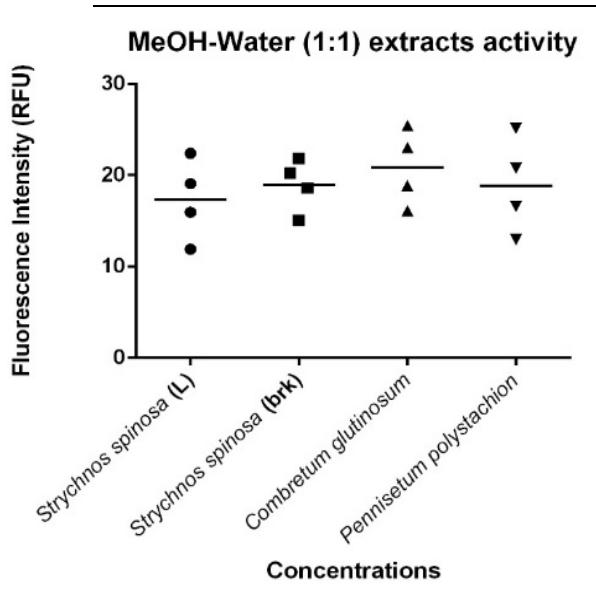


Figure 3: Antiplasmodial activity of Strychnos spinosa stems extracts

Strychnos spinosa barks

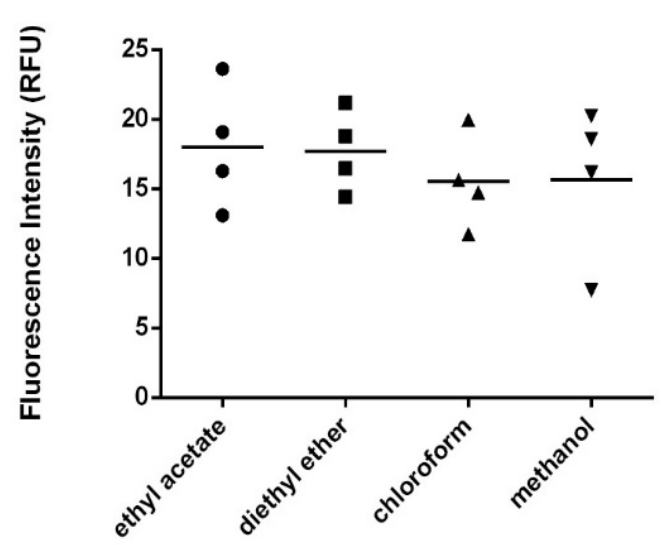

Figure 4: Antiplasmodial activity of Strychnos spinosa

Strychnos spinosa leaves

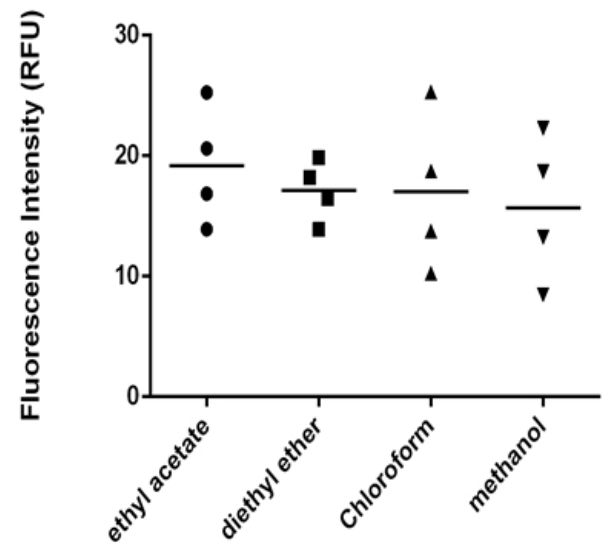

Pennnisetum polystachion

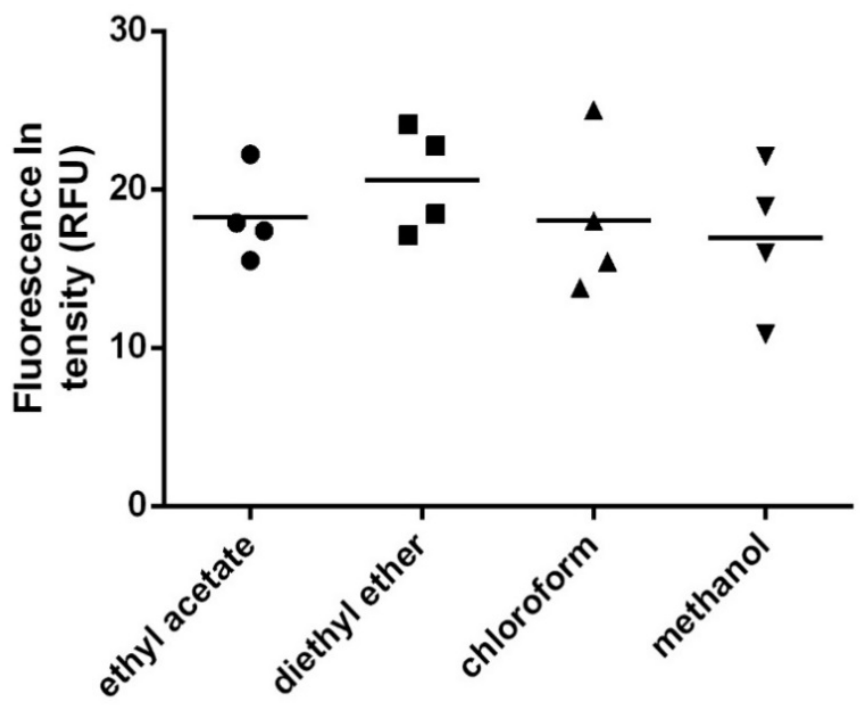

Figure 5: Antiplasmodial activity Pennisetum polystachion extracts

Table III under, represents the concentrations values which cause $50 \%$ inhibition of parasites growth. 
Table III: IC $_{50}$ in absolute value of the various plants extracts studied

\begin{tabular}{cccccc}
\hline \multicolumn{7}{c}{$\begin{array}{c}\text { IC } 50 \text { in } \mu \mathrm{g} / \mathrm{ml} \\
\text { solvaction }\end{array}$} & $\begin{array}{c}\text { Ethyl } \\
\text { acetate }\end{array}$ & $\begin{array}{c}\text { Diethyl } \\
\text { ether }\end{array}$ & Chloroform & Methanol & Methanol/Water \\
\hline C. glutinosum & 41 & 65 & 38 & 45 & 35 \\
P. Polystachion & 28 & 48 & 53 & 33 & 28 \\
S. spinosa (leaves) & 55 & 40 & 20 & 38 & 33 \\
S. spinosa (stems) & 30 & 36 & 16 & 25 & 15 \\
\hline
\end{tabular}

\section{Discussion}

The potential of higher plants as a source of new drugs is still widely unexplored. Among the plants species estimated between 250 000-500 000, only a small percentage were studied, and the phytochemical fractions submitted to biological or pharmacological test are even smaller (Ravikumar and $a l, 2012)$.

Plants great potential as drug sources remains as yet underexploited. For example, among the species that yielded 939 approved molecules, 369 drugs are at clinical trials stage, of which 119 in preclinical trials. About 19800 bioactive natural products belong to only 114 of the 6763 species family known in nature. Moreover, $80 \%$ of approved drugs and $67 \%$ of drugs in clinical trials are concentrated respectively in 17 and 30 prolific drugs families (Zhu and al, 2011).

The medicinal importance of these plants is due to the presence of secondary metabolites products, which are accountable for the plants therapeutic effects observed on the human body (Savithramma and al, 2011). A great number of studies showed that the different chemical clusters identified (Table II), namely flavonoids (Ramazana and al, 2010), tannins, anthracene heterosides, and cardiotonic heterosides (Ravikumar and al, 2011), may have antiplasmodial activities.

The Strychnos spinosa extracts turned out to be the most active, among the extracts tested (Table III). The stems hydromethanolic extract is the most active of all, with a $\mathrm{IC}_{50}$ of $15 \mu \mathrm{g} / \mathrm{ml}$, followed by the chloroformic extracts with a IC 50 of $16 \mu \mathrm{g} / \mathrm{ml}$ (Table III) (figure 3). The Pennisetum polystachion leaves chlorophormic extracts and ethyl acetate extracts (Table III and Figure 5) follow, with respecItive $\mathrm{C}_{50}$ of 20 and $21 \mu \mathrm{g} / \mathrm{ml}$.

Of all the extracts tested, the Combretum glutinosum extracts was the less active (Figure I and Table III).

On the whole, the hydromethanolic blend was the most active among the extraction solvents, followed by chloroform and methanol. Of all tests, ether extracts are the less sensitive (Table III). This hydroalcoholic extract activity is proportional to its extraction yields, followed by those of methanol and ethyl acetate (Table I). These solvents activity was in agreement with the 
studies carried out by (Katuural and al, 2007) and (Sattar and al, 2008) on plant antiplasmodial activity.

These results are interesting according to the following classification: an extract is very active if $\mathrm{IC}_{50}<5 \mu \mathrm{g} / \mathrm{ml}$, active when $5 \mu \mathrm{g} / \mathrm{ml}<\mathrm{IC}_{50}<50$ $\mu \mathrm{g} / \mathrm{ml}$, weakly active if $50 \mu \mathrm{g} / \mathrm{ml}<\mathrm{IC}_{50}<100 \mu \mathrm{g} / \mathrm{ml}$, and inactive if $\mathrm{IC}_{50}>100$ $\mu \mathrm{g} / \mathrm{ml}$ (Bickii and al, 2007). All $\mathrm{IC}_{50}$ obtained are lower than $50 \mu \mathrm{g} / \mathrm{ml}$.

\section{Conclusion}

These encouraging results show again the importance of traditional knowledge about medicinal plants, which are worth exploiting for the purpose of bringing solutions to present day health issues.

However, it is necessary to carry on with efforts to discover new antimalaria matrix molecules from natural plants.

\section{References:}

Madu O., Lemon grass, antidote to malaria, typhoid, pains. Natural essence apothecary (2007): (1):1- 4.

Osayemwenre Erharuyi, Abiodun Falodun, Peter Langer, Medicinal uses, phytochemistry and pharmacology of Picralima nitida (Apocynaceae) in tropical diseases: A review Asian Pacific Journal of Tropical Medicine (2014)1-8

Sarr S.O, Perrotey S., Fall I., Ennahar S., Diop Y.MB., Candolfi E., Marchioni, Icacina senegalensis A. Juss. (Icacinaceae), traditionally used for the treatment of malaria inhibits in vitro Plasmodium falciparum growth without host cell toxicity. Malaria Journal 2011, 10:85 doi:10.1186/14752875-10-85.

Akininyi JA., D. Manadwudu, Sultanaabawa, Ethnobotany of Nigerian medicinal plants: African journal of medicine and medical sciences (2006) 83-112.

Schwikkard S., Van Heerden FR., Antimalarial activity of plant metabolites. Natural Product Reports (2002); 19: 675-692.

Atsushi O., Takaesu K., Natsume M., S. Taba, K. Nasu, M. Uehara And Y. Muramoto, Identification and use of a wild plant with antimicrobial activity against Ralstonia solanacearum, the cause of bacterial wilt of potato. Weed Biology and Management (2004) 4, 187-194

Trease and Evans WC. Pharmacognosy, Edition. XIV, Mac Millian Publ., Ltd., London (1997): 568-578.

Baniecki ML., Wirth DF, Clardy J, High-throughput Plasmodium falciparum growth assay for malaria drug discovery. Antimicrob Agents Chemother (2007), 51:716-723.

Ndiaye D., Patel V., Demas A., LeRoux M., Ndir O., Mboup S., Clardy J., Lakshmanan V., JP. Daily, DF. Wirth, A non-radioactive DAPI-based high- 
throughput in vitro assay to assess Plasmodium falciparum responsiveness to antimalarials-increased sensitivity of $\mathrm{P}$. falciparum to chloroquine in Senegal. The American Journal of Tropical Medicine and Hygiene (2010), 82:228-230.

Ravikumar S., Inbaneson S. J., Suganthi P., In vitro antiplasmodial activity of chosen terrestrial medicinal plants against Plasmodium falciparum, Asian Pacific Journal of Tropical Biomedicine (2012) S252-S256

Zhu F., Qin C., Tao L., Liu X., Shi Z., Ma X., Jia J., Tan Y., Cui C., Lin J., Tan C., Jiang Y. and Chen Y., Clustered patterns of species origins of naturederived drugs and clues for future bioprospecting Proceedings of the National Academy of Sciences (PNAS) (August 2, 2011) vol. 108 no. 31 12943-12948

Savithramma N., Rao M. L. and Suhrulatha D., Screening of Medicinal Plants for Secondary Metabolites. Middle-East Journal of Scientific Research (2011) 8 (3): 579-584

Ramazani A., Sardari S., Zakeri S., Vaziri B., In vitro antiplasmodial and phytochemical study of five Artemisia species from Iran and in vivo activity of two species. Parasitology Research (2010); 107: 593-599.

S. Ravikumar, J acob Inbaneson S, S uganthi P, Gnanadesigan, In vitro antiplasmodial activity of ethanolic extracts of mangrove plants from South East coast of India against chloroquine-sensitive Plasmodium falciparum. Parasitology Research (2011); 108: 873- 878.

Katuura E, Waako P., Tabuti J. R. S., . Bukenya-Ziraba R and Ogwal-Okeng J., Antiplasmodial activity of extracts of selected medicinal plants used by local communities in western Uganda for treatment of malaria, African Journal of Ecology (2007), 45 (Suppl. 3), 94-98

Sattar E. A., Harraz F. M., Al-Ansari S. M. A., El-Mekkawy S., Ichino C., Kiyohara H., Otoguro K., Omura S., Yamada H., Antiplasmodial and antitrypanosomal activity of plants from the Kingdom of Saudi Arabia, Journal of Natural Medicines (2009) 63:232-239

Bickii J., Tchouya G. R. F., Tchouankeu J. C., Tsamo E., Antimalarial activity in crude extracts of some Cameroonian medicinal plants. African Journal of Traditional, (2007) 4(1):107-111. 